\title{
Enzyme-linked immunosorbent assay (ELISA) to detect antibodies in gonorrhoea using whole cells
}

\author{
CATHERINE A ISON, S GAYE HADFIELD, AA GLYNN* \\ From the Department of Bacteriology, Wright-Fleming Institute, St Mary's Hospital Medical School, \\ London W2 1PG
}

SUMMARY The choice of an antigen that will adequately differentiate between infected and noninfected patients has been a major problem in detecting gonococcal antibodies for diagnosis. We have used the sensitive technique of ELISA to test various serotypes of Neisseria gonorrhoeae for their suitability as antigens. Whole cells of each serotype were attached to polystyrene plates using poly-L-lysine. $N$ gonorrhoeae, strain $\mathrm{H} 1$ type 1 was used to detect antibodies in patients with known clinical history and then as a standard to evaluate the ability of different serotypes to differentiate between infected and non-infected groups.

The most satisfactory method of diagnosing an infection is to culture the organism. However, there are situations in which this is difficult or impossible. There may be intrinsic problems in growing the organism, the patient may have received antibiotics or the attempt at diagnosis may be retrospective of infection already subsided. In all these serological methods may be useful. In sexually transmitted diseases, particularly in screening programmes, patients may find it more acceptable to provide a blood sample than a specimen for culture.

In recent years many serological tests for gonorrhoea have been described but none is in routine use. The key factor is the antigen used and an antigen of adequate specificity has not yet been isolated. Preparation of pure antigens involves relatively complex isolation procedures and this can be tedious if it is desired to compare many strain differences. While the ideal of purified antigens with well characterised determinants must not be neglected, the use of whole bacteria, as in classical agglutination tests, would be very convenient in comparing antibody responses to different strains using the sensitive technique of the enzyme-linked immunosorbent assay (ELISA).

Sheep erythrocytes can be attached to polystyrene Petri dishes using poly-L-lysine. ${ }^{12}$ We have modified this method in order to attach whole gonococci to microtitre polystyrene trays for use as an antigen in ELISA.

*Present address: Central Public Health Laboratory, Colindale Avenue, London NW9 5EQ.

Accepted for publication 11 March 1981
Various strains were examined to determine which gave the optimum differentiation between infected and non-infected groups of patients.

\section{Material and methods}

B ACTERIA

Of the strains of $N$ gonorrhoeae, $\mathrm{H} 1$ was originally isolated from a patient at St Mary's Hospital. Colony types 1 and 4 have been kept by repeated selective subculture. F62 types 1 and 4 are descendants of a strain of F62 given by Dr DS Kellogg. Strains A1, B2, C3, D4, G7, H8, N10, S12, T13 and V15 are all colony type 4 and were given by Dr K Johnston. Each possesses an outer membrane protein of different serotype. ${ }^{3}$

The reference strains of $N$ meningitidis, NCTC 10025 serogroup A, NCTC 10026 serogroup B, NCTC 8554 serogroup C, were obtained from the National Collection of Type Cultures (Colindale, England).

All strains were grown in Petri dishes on GC Base Agar (Difco) with supplements of dextrose, $\alpha$ glutamine, cocarboxylase, and ferric nitrate 4 but no antibiotics.

After $18 \mathrm{~h}$ incubation in a carbon dioxide incubator $\left(7 \% \mathrm{CO}_{2}\right)$ at $36^{\circ} \mathrm{C}$, growth from each plate was scraped into $2 \mathrm{ml}$ phosphate-buffered saline (PBS) $(0 \cdot 15 \mathrm{M}, \mathrm{pH} 7 \cdot 4)$. Suspensions were ultrasonicated (15 s at $25 \mathrm{kHz}$ ) to break up clumps and adjusted to an optical density (OD) of $0.5(\lambda=700 \mathrm{~nm})$.

ANTIGEN TITRATION

Each strain was tested by ELISA at increasing 1040 
concentrations against a positive and a negative control serum. All gave curves with a plateau over the range OD $0 \cdot 2-1 \cdot 0$. A standard working concentration of $\mathrm{OD}=0.5$ was therefore used for all strains. The antigen excess ensured that even quite large variations in concentration had little effect.

\section{ANTIBODY DILUTION}

At the antigen concentration chosen, positive and negative control sera were titrated. The dilution giving optimum differentiation between the control sera were used for all sera tested.

PREPARATION OF TRAYS

Flat bottomed polystyrenemicrotitre trays(Dynatech) were used. All the wells in the trays were filled with poly-L-lysine (Sigma), at $50 \mu \mathrm{g} / \mathrm{ml}$ in PBS, and left at room temperature for $30 \mathrm{~min}$. They were then emptied and washed three times with PBS for $3 \mathrm{~min}$ each time.

To half the wells in each tray $100 \mu l$ bacterial suspension (antigen) was added and left for $30 \mathrm{~min}$ at room temperature. The bacteria were then removed by suction into disinfectant, care being taken to avoid bench contamination and production of aerosols. The trays were then washed three times with PBS as before, and filled with $0.2 \%$ glutaraldehyde. They were then washed and stored in $0.1 \mathrm{M}$ glycine at $4^{\circ} \mathrm{C}$ in moist conditions.

\section{ELISA USING POLY-L-LYSINE-ANTIGEN COATED TRAYS}

The trays already prepared were allowed to reach room temperature and washed three times with PBS containing $1 \%$ gelatin to prevent non-specific sticking of serum proteins. To appropriate wells with and without antigen $100 \mu \mathrm{l}$ of serum at a dilution of $1 / 400$ was added and left for $1 \mathrm{~h}$ at $30^{\circ} \mathrm{C}$. Unattached serum proteins were then removed by washing three times with PBS-gelatin. The assay was continued with alkaline phosphatase-conjugated anti-human IgG as already described. 45

\section{POPULATIONS STUDIED}

Sera were taken from four groups.

(1) Males who were known to be smear- or culturepositive for gonorrhoea.

(2) Females who were all culture-positive for gonorrhoea.

(3) Male volunteer medical students as normal controls.

(4) Females from the abortion clinic known to be culture-negative for gonorrhoea, or patients attending the antenatal clinic, who were presumed not to have gonorrhoea.

In initial studies using one strain of $N$ gonorrhoeae,
H1, colony type 1 , there were 100 in each group. The gonococcal patients were of defined clinical history.

In subsequent studies using the other strains of $N$ gonorrhoeae, there were groups of 25 people, again defined above but whose detailed clinical history was not known.

\section{IODINATION OF BACTERIA}

For some experiments bacteria were iodinated with 125I by means of the lactoperoxidase technique. ${ }^{6}$ In these experiments separate wells (Dynatech) were used instead of trays. After the ELISA reaction had been read the wells were counted in a $\gamma$ counter (LKB).

\section{Results}

DETECTION OF ANTIBODIES TO

N GONORRHOEAE H 1, TY PE 1

The 400 sera, as described in Methods, were tested for IgG antibodies using strain $\mathrm{H} 1$, type 1 . The results were expressed in arbitrary units $\left(E_{c r}\right)$ based on corrected extinction values. 4

There was a significant difference between the control and infected groups, the infected patients having a mean four times that of the controls (Table 1). Male and female control groups gave the same mean antibody concentration.

Table 1 IgG antibody to $N$ gonorrhoeae (strain $H 1$ type 1) in patient and control groups

\begin{tabular}{lcc}
\hline & Male & Female \\
\cline { 2 - 3 } & Geometric mean \\
\hline STD patients with proven gonorrhoea & $11.5^{*}$ & 13.9 \\
Normal controls & 2.96 & 2.98 \\
p (Student's $t$ test) & $<0.001$ \\
\hline
\end{tabular}

*In corrected extinction units $\left(\mathrm{E}_{\mathrm{cr}}\right)$.

The potential of this strain to diagnose gonorrhoea can be seen from the cumulative frequencies in each of the groups at different antibody concentrations (Table 2).

When this technique was used to detect IgG antibodies, there was no residual effect of a previous history of gonorrhoea either in males or females even after ten or more separate infections.

There was also no correlation between the antibody concentration, patient age, the presence or absence of symptoms, syphilis or other sexually transmitted diseases. The meningococcal carriage in these groups was not known.

IgG ANTIBODY AGAINST DIFFERENT STRAINS The 10 strains of $N$ gonorrhoeae with different 
Table $2 \%$ positives at different chosen antibody concentrations

\begin{tabular}{llllll}
\hline $\begin{array}{lllll}\text { Arbitrary normal } \\
\text { upper limit }\left(E_{\mathrm{er}}\right)\end{array}$ & \multicolumn{2}{l}{$\%$ Positive } & & \\
\cline { 2 - 3 } & \multicolumn{2}{l}{ Males } & & & Females \\
\cline { 2 - 3 } \cline { 5 - 6 } & Patients & Controls & & Patients & Controls \\
\hline 5 & 73 & 29 & & 76 & 32 \\
10 & 57 & 20 & & 64 & 17 \\
15 & 45 & 12 & & 56 & 11 \\
20 & 35 & 6 & 44 & 6 \\
25 & 30 & 2 & 37 & 2 \\
\hline
\end{tabular}

serotypes were tested against four groups of 25 sera. The geometric mean antibody level of each group varied greatly between strains (Table 3 ).

The differential between patients and controls was generally greater in males than females, the controls being higher in the female group. The possibility that these variations were due to differences in the sticking ability of individual strains was considered. However, radiolabelling studies showed that percentage sticking was not related to the ELISA results obtained (Table 3 ).

Table 3 IgG antibodies against $N$ gonorrhoeae. (Each strain has an outer membrane protein of different serotype)

\begin{tabular}{|c|c|c|c|c|c|}
\hline \multirow[t]{2}{*}{$\begin{array}{l}\text { Serotype strain } \\
\text { (all colony type } \\
\text { 4) }\end{array}$} & \multicolumn{2}{|c|}{$\begin{array}{l}\text { ELISA }\left(E_{\mathrm{cos}}\right)^{*} \\
\text { Geometric mean } \\
\text { Males }\end{array}$} & \multicolumn{2}{|c|}{$\begin{array}{l}\text { ELISA }\left(E_{\mathrm{4Ob}}\right) \\
\text { Geometric mean } \\
\text { Females }\end{array}$} & \multirow[t]{2}{*}{$\begin{array}{l}\% \\
\text { sticking }\end{array}$} \\
\hline & Patients & Controls & Patients & Controls & \\
\hline A1 & $15 \cdot 3$ & $2 \cdot 3$ & $18 \cdot 5$ & $4 \cdot 6$ & $2 \cdot 6$ \\
\hline B2 & $6 \cdot 8$ & $2 \cdot 9$ & $9 \cdot 3$ & $3 \cdot 8$ & $4 \cdot 5$ \\
\hline C3 & $33 \cdot 7$ & $1 \cdot 2$ & $31 \cdot 9$ & $4 \cdot 9$ & $3 \cdot 3$ \\
\hline D4 & $25 \cdot 2$ & $8 \cdot 3$ & $28 \cdot 9$ & $19 \cdot 9$ & $6 \cdot 4$ \\
\hline G7 & $21 \cdot 8$ & $3 \cdot 7$ & $24 \cdot 1$ & $8 \cdot 1$ & $4 \cdot 1$ \\
\hline H8 & $11 \cdot 7$ & 1.6 & $7 \cdot 8$ & $6 \cdot 8$ & $4 \cdot 6$ \\
\hline N10 & $12 \cdot 6$ & $3 \cdot 8$ & 10.9 & $11 \cdot 1$ & $3 \cdot 1$ \\
\hline S12 & $22 \cdot 6$ & $2 \cdot 9$ & $12 \cdot 3$ & $7 \cdot 9$ & $2 \cdot 6$ \\
\hline T13 & $14 \cdot 8$ & $1 \cdot 6$ & $13 \cdot 8$ & $7 \cdot 3$ & $3 \cdot 3$ \\
\hline V15 & $9 \cdot 3$ & $1 \cdot 2$ & $6 \cdot 6$ & $4 \cdot 3$ & $5 \cdot 0$ \\
\hline †SE (range) & $0 \cdot 3-0.9$ & $0 \cdot 3-2 \cdot 1$ & $0 \cdot 4-1 \cdot 0$ & $0 \cdot 4-2 \cdot 0$ & $0 \cdot 4-2 \cdot 2$ \\
\hline
\end{tabular}

* Results given in crude uncorrected extinction units. †Individual standard errors are not given to simplify the table.

\section{IgG ANTIBODIES AGAINST DIFFERENT}

COLONIAL TYPES

Antibody activity against the strains $\mathrm{H} 1$, and F62 was measured using whole cells of both colony types 1 and 4 . There was significantly more antibody detected against type 1 than 4 (Table 4). This is probably due to the presence of pili on colony type 1 , as the variations were not due to differences in sticking.

CROSS-REACTIONS

Neisseria meningitidis was also used as an antigen
Table 4 Geometric mean IgG antibody in 25 patients and 25 controls tested against $N$ gonorrhoeae of different colony types

\begin{tabular}{|c|c|c|c|c|c|c|}
\hline \multicolumn{2}{|c|}{$\begin{array}{l}\text { Strain } \\
\text { (colony type) }\end{array}$} & \multicolumn{2}{|c|}{$\begin{array}{l}\text { ELISA }\left(E_{405}\right)^{*} \\
\text { Males }\end{array}$} & \multicolumn{2}{|c|}{$\begin{array}{l}\text { ELISA }\left(E_{405}\right) \\
\text { Females }\end{array}$} & \multirow[t]{2}{*}{$\begin{array}{l}\% \\
\text { sticking }\end{array}$} \\
\hline & & Patients & Controls & Patients & Controls & \\
\hline H1 & T1 & $31 \cdot 5$ & $8 \cdot 1$ & $48 \cdot 4$ & $11 \cdot 5$ & 1.68 \\
\hline H1 & T4 & $15 \cdot 8$ & $7 \cdot 3$ & $28 \cdot 6$ & $12 \cdot 7$ & $1 \cdot 75$ \\
\hline F62 & T1 & $18 \cdot 1$ & $8 \cdot 6$ & $14 \cdot 3$ & $9 \cdot 1$ & 2.92 \\
\hline F62 & T4 & $9 \cdot 8$ & $7 \cdot 8$ & $7 \cdot 7$ & $7 \cdot 1$ & $1 \cdot 87$ \\
\hline \multicolumn{2}{|c|}{ †SE (range) } & $0.3-0.8$ & $0.5-0.7$ & $0.7-0.9$ & $0.4-0.8$ & $0 \cdot 1-1 \cdot 2$ \\
\hline
\end{tabular}

* Results given in crude uncorrected extinction units.

†Individual standard errors are not given to simplify the table.

and detected IgG antibodies in patients with proven gonorrhoea (Table 5). By means of a whole cell technique, cross-reactions between species of the same genus are not unlikely.

Table 5 Geometric mean IgG antibody levels in 25 patients with gonorrhoea and 25 controls tested against serogroups of $N$ meningitidis

\begin{tabular}{|c|c|c|c|c|c|}
\hline \multirow[t]{2}{*}{ Strain } & \multicolumn{2}{|c|}{$\begin{array}{l}\text { ELISA }\left(E_{405}\right)^{*} \\
\text { Males }\end{array}$} & \multicolumn{2}{|c|}{$\begin{array}{l}\text { ELISA }\left(E_{405}\right) \\
\text { Females }\end{array}$} & \multirow[t]{2}{*}{$\begin{array}{l}\% \\
\text { sticking }\end{array}$} \\
\hline & Patients & Contrals & Patients & Controls & \\
\hline $\begin{array}{l}N \text { meningitidis } \\
\text { (A) } \\
\text { (B) } \\
\text { (C) }\end{array}$ & $\begin{array}{l}14 \cdot 7 \\
13 \cdot 3 \\
20 \cdot 6\end{array}$ & $\begin{array}{l}4 \cdot 5 \\
1 \cdot 1 \\
2 \cdot 6\end{array}$ & $\begin{array}{r}14 \cdot 0 \\
11 \cdot 2 \\
7 \cdot 2\end{array}$ & $\begin{array}{l}7 \cdot 4 \\
4 \cdot 2 \\
5 \cdot 2\end{array}$ & $\begin{array}{l}2 \cdot 8 \\
2 \cdot 0 \\
2 \cdot 8\end{array}$ \\
\hline †SE (range) & $0.4-0.6$ & $0 \cdot 5-1 \cdot 2$ & $0.5-0.8$ & $0 \cdot 5-0.8$ & $0 \cdot 5-1 \cdot 5$ \\
\hline
\end{tabular}

* Results given in crude uncorrected extinction units.

fIndividual standard errors are not given to simplify the table.

\section{Discussion}

Initial studies showed it is possible with a single strain of $N$ gonorrhoeae to differentiate between infected and non-infected groups. Using a cut-off level of 15 corrected extinction units $\left(E_{c r}\right)$, approximately $50 \%$ of patients with acute gonorrhoea could be diagnosed and this is comparable to studies with purified antigens. ${ }^{4} 7$

The aim of the present work was to determine if any particular serotype would differentiate between groups more efficiently. Of the 10 serotypes studied, it would appear for our geographical area, that strain C3 may be particularly useful. It was not $\mathrm{C}$ possible for us to correlate the serotype of strain C3 with that of our infecting strains, as their outer 0 membrane protein serotype was not known.

It is interesting that these strains with different serotypes which came from America gave very low antibody levels with our normal male controls.

The whole cell technique has the advantage of 
using an antigen which was easy and quick to prepare. The trays can be prepared in bulk and stored in moist conditions for at least three months without deterioration. The test could be used with two or more strains to increase the predictive value, ${ }^{8}$ in a similar way that two different antigens are used in the serodiagnosis of syphilis. The possible application of this technique to other bacteria is being investigated. Preliminary results have shown that antibody can be detected to $\beta$-haemolytic streptococcoci (group B) and we have detected IgG antibodies in a patient known to be a carrier.

Salmonella and Escherichia coli attached to poly-L-lysine coated trays have been used in our department to detect both human and mouse antibodies. So too has Staphylococcus aureus though it is important to use a protein A-deficient strainfor example, Wood 46.

Clinical bacteriology has exploited new quantitative and sensitive techniques such as ELISA much less than some other disciplines such as virology and parasitology. ${ }^{8}$ Most bacteria have a negative surface charge and the ability to attach them readily to polystyrene trays via poly-L-lysine should encourage further development.

We thank Dr KH Johnston for the gift of $N$ gonorrhoeae serotypes and Mrs C Bellinger for technical assistance. The work was supported by a grant from the Medical Research Council, England.

\section{References}

${ }^{1}$ Kedar E, de Landazuri O, Bonavida B. Cellular immunoadsorbents: a simplified technique for separation of lymphoid cell populations. J Immunol 1974;112:1231-43.

2 Kennedy JC, Axelrod MA. An improved assay for haemolytic plaque forming cells. Immunology 1971;20:253-7.

3 Johnston KH, Holmes KK, Gotschlich EC. The serological classification of Neisseria gonorrhoeae. 1. Isolation of the outer membrane complex responsible for serotypic specificity. $J$ Exp Med 1976;143:741-58.

4 Glynn AA, Ison CA. Serological diagnosis of gonorrhoea by an enzyme-linked immunosorbent assay (ELISA). $\mathrm{Br}$ J Vener Dis 1978;54:97-102.

5 Ison CA, Glynn AA. Classes of antibodies in acute gonorrhoea. Lancet 1979;ii:1165-8.

- Heckels JE. The surface properties of Neisseria gonorrhoeae: topographical distribution of the outer membrane protein antigens. J Gen Microbiol 1978;108:213-9.

${ }^{7}$ Buchanan TM, Swanson J, Holmes KK, Krans SJ, Gotschlich EC. Quantitative determination of antibody to gonococcal pili. Changes in antibody levels with gonococcal infection. J Clin Invest 1973;52:2896-909.

${ }^{8}$ Glynn AA, Ison CA. Immunoassays in bacteriology. In: Voller A, Bidwell DE, Bartlett A, eds. Immunoassays for the 80's. Lancaster: MTP Press, 1981:431.

Requests for reprints to: Professor AA Glynn, Director, Central Public Health Laboratory, 175 Colindale Avenue, London NW9, England. 